\title{
INSTITUSI MINORITAS DAN STRUKTUR SOSIAL DI INDIA
}

\author{
Raudatul Ulum \\ Puslitbang Bimas Agama dan Layanan Keagamaan \\ Balitbang dan Diklat Kementerian Agama RI \\ gelombanglaut@gmail.com
}

\begin{abstract}
Policy of management of religion is a specific challenge in the modern era. State and religion experience a dynamic relation. In the policy perspective, anything related to religion is always controversial from its initial idea to the implementation. In many countries, the position of religion toward state is not always beneficial. Up and down relations between both is very much influenced by power interest. This research on the policy of religion management in India aims at understanding efforts of the state in order to manage relations of religious majority and minority in India, comprehending related policies and their implementations, as well the existence of regulation of religion management in India. There are three religious minorities in India and they are treated as affirmative policy. They are religious minority, (other than Hindus), indigenous local tribes, and backward caste. A unique social relation occurs between low-caste Hindus and Muslim institutions. The policy of Aligarh Muslim University which granted scholarships for poor society has contributed some changes. Interreligious conflicts have become important issues to describe the circumstances of society and policy in India. Religious services are conducted by using the term religious minority which focuses on education matters. This research is conducted through limited observation techniques, deep interview, and document analysis. This research concludes that state policy related to the treatment toward religious minority, which at the same time also works for other two religious minorities, has been effective, although it does not change much social system which has been running through the history of modern India.
\end{abstract}

Keywords: India, Minority, Religion, Tribe, Caste.

\begin{abstract}
Abstrak
Kebijakan tentang pengaturan agama merupakan tantangan tersendiri di era modern. Hubungan negara dengan agama saat ini sedemikian dinamis. Dalam pespektif kebijakan, segala hal menyangkut agama kerap kontroversial sejak dari munculnya gagasan sampai dengan pelaksanaannya. Di berbagai negara, posisi agama terhadap negara tidak selalu menguntungkan, pasang surut relasi keduanya sangat dipengaruhi oleh kepentingan kuasa. Penelitian terhadap kebijakan pengaturan agama di India bertujuan untuk memahami bagaimana upaya yang dilakukan negara dalam hal mengelola kehidupan hubungan mayoritas dengan minoritas agama di negaranya, Memahami kebijakan dalam kehidupan keagamaan apa saja yang telah dilakukan oleh India dan bagaimana implementasinya, dan memahami tentang adanya peraturan pelayanan keagamaan. Penanganan minoritas agama di India setidaknya disebutkan tiga minoritas yang secara umum dikenal di India dan diberlakukan affirmative-policy. Minoritas agama, selain penganut Hindu, penganut agama lain sebagai minoritas agama, berikutnya suku-suku rentan yang sulit mengakses kebijakan, dan ketiga adalah backward caste. Relasi sosial yang unik terjadi antara penganut Hindu yang berkasta rendah dengan institusi muslim cukup unik, kebijakan Aligarh Muslim University yang memberikan beasiswa masyarakat miskin dan rentan cukup memberikan arti terhadap perubahan. Konflik antaragama juga bagian dari isu penting untuk menggambarkan keadaan masyarakat dan kebijakan di India. Pelayanan keagamaan dilakukan dengan mengenalkan istilah institusi minoritas yang fokus pada urusan pendidikan. Penelitian dilakukan dengan teknik observasi terbatas, wawancara mendalam dan analisis dokumen. Penelitian ini memeroleh kesimpulan bahwa kebijakan negara menyangkut penanganan minoritas agama yang sekaligus mengurusi dua minoritas lainnya cukup efektif meskipun tidak banyak mengubah sistem sosial yang sudah berlangsung sepanjang sejarah India modern.
\end{abstract}

Kata Kunci: India, Minoritas, Agama, Suku, Kasta. 


\section{PENDAHULUAN}

Studi terhadap kebijakan penanganan minoritas di berbagai negara merupakan satu hal penting dilakukan, hal tersebut dimaksudkan untuk memahami bagaimana negara dapatberperan diruang publik dan berdialog masuk pada ruang privat. Kehidupan keagamaan berada di titik krusial antara ruang privat dan ruang publik. Posisi dialogis ini banyak dibahas oleh Clarke E. Cochran dalam bukunya Religion in Public and Private Life (2015). Berbagaai isu yang awalnya adalah domain privat akhirnya menjadi kajian di ruang publik. Ada dualisme yang paralel dalam diskursus negara, agama dan ruang publik, selama ini dikotomi gerejasuci-privat versus negara-sekular-publik (Cochran 2015, hal 1). Dualisme jalur antara agama dan negara ini seringkali tidak konsisten, terutama menyangkut isu-isu yang berkembang, hingga saat ini, dari aborsi sampai dengan pendidikan agama. Pendidikan agama di negara sekuler sepenuhnya diserahkan kepada keluarga ataupun komunitas pada agama tersebut, sampai munculnya reaksi akhir akhir ini terutama tahun 2015-2016, isu pendidikan agama di Amerika Serikat sempat mengemuka menjadi tuntutan sebagian warga negara terhadap anak mereka. Kehidupan keagamaan berada diantara garis publik dan privat, kondisi tersebut terjadi di hampir semua negara yang menganut sistem modern, terurtama republik dan demokrasi.

Perlakuan negara terhadap pemeluk agamamenentukancorakhubunganantara negara dengan rakyatnya, bagaimana hal tersebut dapat menciptakan harmoni dan mencegah konflik antaridentitas, baik itu kultur, etnik, agama bahkan politik atau ideologi. Bagaimana negara menempatkan diri diantara para pemeluk agama yang berbeda. Hubungan yang dimaksud, intinya tergantung dengan sistem yang pilih, sebagai negara sekuler maupun agama. Beberapa negara yang secara jelas menempatkan agama sebagai dasar dari sistem negara tersebut tentunya spirit agama dan pengaturan etik didalamnya akan memengaruhi penyelenggaraan negara, mulai produk hukum dan perundangan sampai dengan tingkat regulasi paling teknis. Namun berbeda dengan negara yang menganut sekularisme, agama adalah wilayah privat tidak menjadi kewajiban negara untuk memberikan layanan dan intervesi apapun.

India adalah negara yang menarik untuk dikaji, setting sosial dengan banyaknya pemeluk agama yang hidup berdampingan dan begitu gampangnya kelompok keagamaan (religious group) tumbuh berkembang di India adalah suatu hal yang menarik. Belum lagi, aspek kesejarahan di masa lalu antara India dengan Indonesia yang tidak bisa dilupakan begitu saja. India adalah masa lalu bagi Indonesia terutama menyangkut asal mula peradaban tua Nusantara, baik itu agama, kerajaan dan kebudayaan yang dibentuk dari nilai persilangan tersebut. Hulu peradaban nusantara boleh dikatakan adalah hindustan. Setidaknya agama Hindu yang jelas-jelas datang dari India memberi warna yang sangat kental terhadap sejarah politik, agama, kultur serta kehidupan sosial masa lalu dan masa kini di Nusantara. Hindu menjadi agama yang pertama kali datang ke Indonesia. Selanjutnya Islam juga diyakini datang atau melewati Gujarat, satu negara bagian yang kental dengan budaya Islam India, teori kedatangan Islam dari Gujarat paling mengemuka bersamaan dengan lalu lintas perdagangan ke Nusantara, lintasan tersebut disebut dengan jalur sutra di masa pertengahan. Mengutip paper Prof. Iwan Pranoto, atase pendidikan dan kebudayaan Kedutaan Besar Republik Indonesia New Delhi, seiring dengan berkembangnya ajaran Buddha, yang secara gamblang sejarah 
mencatat hubungan antara Nalanda dan Sriwijaya (Iwan Pranoto, Contemplating the knowledge route, 2017, 23-24) sebagai knowledg route. Di dalam paper tersebut dipaparkan tentang kegemilangan Sriwijaya sebagai pusat pendidikan Buddha yang dapat ditarik jalur pengetahuan pada perpustakaan terbesar di zamananya, Nalanda India Utara, Uttar Pradesh.

Penelitian ini dilakukan secara kualitatif, disajikan secara deskriptif analitik. Analisis dilakukan dengan narasi dengan pola mengalir, berdasarkan hasil interaktif terhadap wawancara, observasi dan kajian dokumen yang didasarkan pada arus data dan informasi awal sampai kunci. Secara konsep penelitian didahului dengan kajian regulating religion, yaitu pengelolaan agama dalam ruang kebijakan yang tidak bisa dilepaskan dari unsur regulasi dan institusi. Aspekaspek yang diatur mencakup kehidupan personal yang bersifat privat, maupun kehidupan sosial yang bersifat publik. Ini menyangkut hal-hal seperti seksualitas, badan manusia, keluarga, pendidikan, budaya, kesejahteraan sosial, kewajiban ekonomi, organisasi dan ideologi politik, perlindungan kaum minoritas, perlindungan konsumen, hingga ke norma-norma hubungan internasional (Beckford dkk, 2007 hal 396-416). Institusi merupakan subjek dari kebijakan itu sendiri, sedangkan regulasi merupakan aturan main terpenting dalam hal mengatur hubungan negara sebagai regulator, institusi penerima mandat, tugas dan kewenangan, kemudian kelompok penganut agama sebagai subjek pelaku keagamaan dan objek dari regulasi.

Aspek hubungan sosial dimulai dengan memahami relasi, sebagai suatu jaringan yang terwujud karena interaksi antara satuan-satuan yang aktif (Kuntjaraningrat 2003, hal 79). Definisi ini menunjukkan bahwa hakekat dari relasi atau hubungan adalah adanya interaksi. Interaksi yang tersirat dalam konsep relasi dalam penelitian ini adalah interaksi sosial, hal dimaksud adalah jaringan hubungan antara dua orang atau lebih atau antara dua golongan atau lebih yang menjadi syarat bagi kehidupan bermasyarakat (Kuntjaraningrat, 2003 hal 90).

Sedangkan Ashutosh Varshney dalam rangka melihat hubungan ikatan-inter-komunal-atau jaringan dan yang mengintegrasikan dua pemeluk agama. Dalam hal ini Robert Putnamm menyebut hubungan ini sebagai modal sosial yang menjembatani (bridging); kemudian hubungan antarpemeluk di luar ikatan atau organisasi yang beranggotakan seagama, adalah modal sosial yang mengikat(bonding).Selanjutnya Varshney membagi jaringan menjadi dua bentuk: a) asosiasional, yakni sebagai bentuk ikatan kewargaan ke dalam organisasi bisnis, ikatan profesi, klub olah raga, dan serikat buruh; b) quotidian, adalah hubungan keseharian yang terbentuk ke dalam ikatan yang tidak membutuhkan organisasi, atau berupa interaksi kehidupan yang sederhana dan rutin, seperti saling kunjung atara keluarga yang berbeda agama, kegiatan makan bersama, berpatisipasi bersama dalam upacara-upacara hari kemerdekaan, mengizinkan anak-anak mereka untuk bermain bersama di lingkungan (Varsney, 2009 hal 144). Konsep berikutnya adalah minoritas (minority), yaitu golongan sosial yang jumlah warganya jauh lebih kecil dibandingkan dengan golongan lain dalam suatu masyarakat dan yang karena itu didiskriminasi oleh golongan lain itu (Varsney, 2009 hal 151). Sebagai penegasan konsepsi minoritas dapat melihat pendapat Reading, adalah kelompok yang menjadi subpopulasi tetapi mempunyai arti secara sosial (Reading, 1986 hal 254). 
Penelitian dilakukan bertujuan pada beberapa hal, pertama memahami bagaimana upaya yang dilakukan negara India dalam hal mengelola kehidupan hubungan mayoritas dengan minoritas agama di negaranya?, berikutnya adalah memahami kebijakan dalam kehidupan keagamaan apa saja yang telah dilakukan oleh India dan bagaimana implementasinya?, selanjutnya memahami tentang adanya peraturan pelayanan keagamaan.

\section{METODE}

Penelitian dilakukan dengan metode wawancara mendalam, observasi terbatas, kajian naskah (analisa dokumen), focused group discussion terhadap pejabat National Comission for Minority Affairs, pejabat institusi minoritas, pemeluk agama minoritas di Indonesia. Penelitian lapangan dilakukan selama 12 hari, 1 s.d. 12 November 2016. Data dikumpulkan melalui teknik wawancara yang dilakukan terhadap pimpinan Komisi Nasional untuk Minoritas, pimpinan dan profesor Aligarh Muslim University, mahasiswa, pengasuh ma'had Darool Ulum Lucknow, profesor pada Jamia Millia Islamia University New Delhi. Observasi langsung pada institusi minoritas Aligarh Muslim University, kajian dokumen laporan tahunan National Commission for MinorityAffairs 2015.

\section{HASIL DAN PEMBAHASAN}

India adalah negara dengan wilayah daratan yang sangat luas dan sering disebut sebagai anak benua (subcontinent). Letaknya berada di bawah, atau di bagian selatan benua utama Asia. Anak benua ini berbentuk seperti segitiga terbalik, membentang dari pegunungan Himalaya yang tinggi di utara, hingga Samudera Hindia di selatan yang memisahkannya dari negara pulau Sri Lanka. Laut Arabia menjadi batas sebelah barat, sedangkan Teluk Benggala sebelah timurnya (Walsh, 2006 hal $1-2)$.

Batas-batas alam anak benua ini, yaitu lautan dan pegunungan, membuatnya terlindung dari migrasi atau serangan biasa. Akses daratan bagi para pedagang, imigran atau penyerang hanya mungkin melalui celah-celah di bagian baratlaut, yaitu Celah Bolan melalui Afganistan menuju bagian timurlaut Iran, atau melalui Celah Khyber dan Lembah Swat yang lebih ke utara, yang menuju Asia Tengah. Inilah jalan raya perdagangan yang menghubungkan India dengan wilayah peradaban Mesopotamia di Timur Tengah, dan dengan Asia Tengah, terus menuju China, melalui "Jalur Sutera". Demikian pula lautan di barat, selatan dan di timur anak benua India, menjadi pelindung alamiah dari invasi. Bagaimanapun, para pedagang tetap dapat memanfaatkan lautan untuk kontak-kontak dagang yang intensif. Para pedagang Arab, Persia maupun India, telah lama diketahui mengembangkan perdagangan samudera jarak jauh ke timur hingga ke Jawa, Sumatera, Bali, dan bahkan China. Kelak bangsa-bangsa Eropa menggunakan jalur samudera ini untuk tujuan dagang sekaligus kolonialisasi (Walsh, 2006 hal 3 - 4).

Sejarah India bisa ditelusuri kembali setidaknya sejak 5.500 tahun silam atau lebih, ketika peradaban Harappa mengembangkan kehidupan menetap di dataran Sungai Indus yang subur. Peradaban ini adalah salah satu dari tiga kelompok masyarakat berperadaban pertama di dunia, selain Mesopotamia dan Mesir. Selama berabadabad, sejumlah bangsa yang berbeda menginvasi India dan menguasai sumber daya alamnya yang luas. Bangsa asing terakhir yang memerintah India adalah Inggris. Kehadiran dan dominasi mereka 
berlangsung di tengah proses keruntuhan sejumlah pemerintahan tradisional India, seperti Moghul dan Bahmani yang Muslim, atau Maratha, Rajput, dan Vijayanagar yang Hindu. India menjadi bangsa modern yang merdeka di tahun 1947, setelah Perang Dunia II. Pada tahun itu, Inggris menarik diri dari anak benua, setelah membagi sebagian besar wilayah menjadi dua negara, India dan Pakistan. India memiliki penduduk lebih dari 1,2 miliar orang, dan menjadi negara kedua di dunia yang paling besar jumlah penduduknya setelah China, sekaligus menjadi negara demokrasi terbesar di dunia (Walsh, 2006 hal 72 -92. Lihat juga Http://Www.Kembangpete.Com/2014/08/22/ Profil-Lengkap-Negara-Indial, diakses 5 November 2016).

\section{Bentuk Negara dan Pemerintahan}

Secara konstitusional, India berbentuk republik dan disebut dengan Republic of India, beribukota di New Delhi dan menganut sistem demokrasi parlementer. India merupakan negara serikat atau federal, terdiri atas 29 negara bagian, termasuk negara bagian Telangana yang baru dibentuk pada 2 Juni 2014 (Kasyap C. Subhash, Our Contitution, 2015, hlm. 80-84. Lihat juga Rajesh Kumar, Universal's Guide to the Constitution of India, 2016, hlm. 72), dan tujuh teritori perserikatan (union territories). Pemerintahan didasarkan atas konstitusi yang diadopsi pada 1950 dan memiliki fitur kombinasi antara model pemerintahan AS yang menekankan prinsip supremasi konstitusi tertulis, pemisahan kekuasaan, dan peninjauan hukum (judicial review), dengan sistem parlementer dan konvensi yang kuat model Inggris. Kekuasaan Eksekutif Pemerintah Federal dipimpin oleh Presiden sebagai kepala negara, yang posisinya sama seperti raja dalam Konstutusi Inggeris, yaitu melaksanakan tugas-tugas pemerintahan sebagaimana ditetapkan Konstitusi (Article 53 (1) Constitution of Republic Of India). Dalam pelaksanaan administrasi pemerintahan sehari-hari, tugas Presiden bersifat seremonial, karena tugas itu dilakukan sepenuhnya oleh Perdana Menteri dan Dewan Menteri-menteri yang ditunjuknya. Perdana Menteri biasanya merupakan pemimpin partai politik yang memiliki jumlah kursi terbanyak di parlemen.

Di setiap negara bagian, terdapat seorang gubernur yang ditunjuk oleh presiden, biasanya berasal dari negara bagian lain, sehingga diharapkan mampu mengambil jarak dari politik setempat dan bersikap objektif. Tetapi, gubernur kadangkala dianggap sebagai kepanjangan tangan Pemerintah Pusat. Posisi dan tugas gubernur menyerupai Presiden di tingkat federal. Selain gubernur, terdapat Ketua Menteri (Chief Minister) yang ditunjuk oleh gubernur dari partai yang memperoleh mayoritas kursi legislatif negara bagian (Vidhan Sabha) hasil pemilu negara bagian yang bersangkutan. Di lima negara bagian, terdapat lembaga legislatif bikameral, sehingga selain Vidhan Sabha, ada kekuasaan legislatif lain hasil campuran pemilihan langsung, pemilihan tidak langsung, dan penunjukan, yang disebut Vidhan Parishad (Legislative Council).

Parlemen adalah kekuasaan legislatif yang melaksanakan fungsi legislasi meskipun tidak memiliki kontrol dan kedaulatan sepenuhnya. Dalam legislasi, Parlemen berbagi kedaulatan hukum dengan Mahkamah Agung (Supreme Court) yang menguji produk perundangan. Badan legislatif nasional, atau parlemen (Sansad), terdiri atas dua rumah. Pertama, Majelis Rakyat (Lok Sabha) yang dipilih langsung oleh rakyat, kecuali beberapa anggota yang dapat ditunjuk oleh presiden. Masa jabatannya 
biasanya lima tahun. Kedua, Majelis Negara Bagian (Rajya Sabha), yang anggotanya dipilih untuk masa jabatan 6 tahun oleh badan legislatif negara bagian. Beberapa anggota juga diangkat oleh Presiden. Presiden dan wakil presiden dipilih untuk masa jabatan 5 tahun oleh electoral college (lembaga pemilihan) yang terdiri atas para anggota legislatif nasional/federal, dan para anggota legislatif negara-negara bagian.

\section{Penduduk dan Bahasa}

India telah menjadi tempat berbaurnya berbagai kelompok etnis sejak awal sejarahnya. Namun, sebagian besar rakyatnya adalah keturunan Dravida 28 persen dan (Indo) Arya 72 Persen ( $h t t p: / /$ adaniel.tripod.com/aryans.htm, diakses 01/12/2016). Orang Dravida telah tinggal di India sejak zaman prasejarah. Orang Indo-Arya pertama kali tiba di benua itu sekitar tahun 1.500 SM. Kedua kelompok itu berbeda dalam penampilan, bahasa, dan adat istiadatnya. Orang Indo-Arya berbicara menggunakan bahasa yang terkait dengan bahasa-bahasa Eropa modern dan keyakinan agama mereka berkembang menjadi Hindu. Indo-Arya menjadi orang yang dominan di India, khususnya di utara. India Selatan tetap didominasi orang Dravida (Encyclopædia Britannica Online: https://www.britannica. com/topic/Indian-languages/. Diakses 1 Desember, 2016).

Menurut Joseph E. Schwartzberg (1993), sebagai kontributor dan editor buku A Historical Atlas of South Asia. Oxford University Press; Reprint, Subsequent edition, mengungkapkan bahwa bahasa utama India dapat dibagi menjadi dua kelompok besar, pertama adalah bahasa resmi Pemerintah Federal Republik India adalah Hindi dalam aksara Dewanagari dan kedua adalah bahasa Inggris. Joseph menjelaskan bahasa yang ada di India utara, barat, dan timur berasal dari bahasa Sansekerta kuno, bahasa Indo-Eropa dan bahasa suci agama Hindu. Bahasa-bahasa itu meliputi Hindi, Assamese, Bengali, Dogri, Gujarati, Kashmir, Marathi, Oriya, Punjabi, Sindhi, Urdu, dan Hindustan. Bahasa-bahasa di selatan seperti Kannada, Malayalam, Tamil, dan Telugu adalah anggota keluarga bahasa Dravida. Tapi bahasa-bahasa itu telah dipengaruhi oleh bahasa Sansekerta. Adapun bahasa Kashmir dan Urdu juga mengandung banyak kosakata dari bahasa Arab dan Persia.

Bahasa Hindi, bahasa nasional, dituturkan oleh sekitar 40 persen dari populasi. Orang India yang paling terdidik menggunakan bahasa Inggris, bahasa Hindi dan bahasa daerah mereka. Anak-anak India diajarkan bahasa daerah mereka dan bahasa Hindi di tingkat sekolah dasar dan menengah pertama. Kemudian mereka juga dapat belajar bahasa Inggris, Sansekerta, atau Persia. Menurut Sensus 2001, India memiliki 122 bahasa utama dan 1599 bahasa lainnya. Namun, terdapat jumlah yang berbeda dari berbagai sumber lainnya, utamanya karena perbedaan definisi "bahasa" dan "dialek". Sensus 2001 menyatakan bahwa 30 bahasa digunakan oleh lebih dari sejuta penduduk asli dan 122 bahasa dipakai oleh lebih dari 10,000 orang.

\section{Agama dan Institusi Minoritas}

Dalam sistem kenegaraan India, secara tegas disebutkan bahwa India adalah negara sekular yang memisahkan urusan agama sepenuhnya dari urusan pemerintahan. Meskipun demikian, dalam hal penjaminan hak hak pemeluk agama dan eksistensi agama-agama, PemerintahanIndiamemilikiKementerian Urusan Minoritas dan Komisi Nasional untuk Minoritas yang merujuk kepada pemeluk agama-agama non Hindu. 
Kedudukan agama diakui bagi kelompok agama minoritas, sedangkan mayoritas adalah Bharat, yakni nama lain dari India. Hampir semua agama besar di dunia ada di India. Sebagian besar orang-orang India beragama Hindu. Umat Islam,
Kristen, Sikh, Budhhis, Jainisme dan Zoroaster sebagai minoritas, diakui dalam konstitusi dan Undang-undang tentang minoritas di India. Berikut jumlah dan persentase populasi minoritas di India, Tabel 1:

Tabel 1: Populasi India berdasarkan Agama dan persentase Minoritas

\begin{tabular}{|l|l|r|l|c|}
\hline No & \multicolumn{1}{|c|}{ Komunitas } & Total populasi & $\begin{array}{c}\text { Persentase } \\
(\%)\end{array}$ & $\begin{array}{c}\text { Persentase minoritas } \\
(\%)\end{array}$ \\
\hline 1 & Hindu & 1.026 .769 .000 & 80,46 & 72 \\
\hline 2 & Muslim & 138.000 .000 & 13,49 & 12,7 \\
\hline 3 & Kristen & 24.000 .000 & 2,3 & 10,14 \\
\hline 4 & Sikh & 19.200 .000 & 1,9 & 04,19 \\
\hline 5 & Buddha & 795.500 & 0.8 & 0,04 \\
\hline 6 & Jain & 454.200 & 0.4 & \\
\hline 7 & Zoroaster & 6.900 & 0.007 & \\
\hline 7 & Lain lain & 774.400 & 0.64 & \\
\hline & & 1.210 .000 .000 & & \\
\hline
\end{tabular}

Sumber: Sensus 2001, Sensus 2001. Dikutip dari buku Muhammad Allam: Indian Minorities in Higher Education (Aligarh, Miskat Printers and Publishers, 2015), 10.

Muslim dianggap penganut minoritas di India, minoritas dilihat dari aspekjumlah saja, seperti halnya penganut agama lain di tengah pemeluk Hindu, sebagai mayoritas $(72 \%)$ di. Kemudian Kristen termasuk Protestan, Ortodoks dan Katolik (12,7\%) adalah minoritas kedua. Selanjutnya secara berurutan Sikh, Buddha, Jainisme dan Zoroaster. Ada beberapa kelompok agama yang secara resmi belum diakui sebagai minoritas, atau dengan kata lain tidak mengalami kebijakan afirmasi oleh negara. Penganut Baha'i dan Yahudi diakui oleh Komisi Nasional untuk Minoritas (National Commission for Minorities). Jumlah mereka relatif cukup banyak, dan khususnya Baha'i, tersebar di hampir semua negara bagian di India (wawancara dengan Zena Sorabjee, trustee Baha'i Council India, 8/11/2016). India tidak mengenal registrasi agama, hanya saja beberapa negara bagian memiliki peraturan tentang Anti Konversi. Konsekuensinya adalah agama-agama yang ada diregistrasi dan pemeluknya secara resmi dipantau dan dikenali oleh negara (bagian).

Hindu adalah identitas kultural di India, seperti nama yang dilekatkan pada bharat, sebutan lain dari kebudayaan Hindi baik sebagai komunitas maupun etnisitas. Hindu sebagai agama, memiliki pemeluk terbesar di India menjadi basis budaya bangsa. Hindu memiliki empat keyakinan penting. Pertama, pemeluknya percaya kepada Tuhan (atau dewa-dewa yang merupakan manifestasi dari dewa tunggal atau roh universal) sebagai pencipta dan penopang alam semesta. Kedua, mereka percaya kepada batin yang kekal, yang akhirnya menyatu dengan Tuhan. Ketiga, mereka percaya kepada adanya tugas suci dan tanggung jawab moral (dharma). Terakhir, mereka percaya kepada hukum aksi dan reaksi (karma), karena memiliki kehendak atas diri sendiri dan menentukan tindakan serta nasib sendiri. 


\section{Institusi Minoritas pada Pendidikan}

Pendidikan dan isu minoritas di India merupakan suatu tema tersendiri. Meskipun secara umum pendidikan adalah tanggung jawab negara dan pemerintah pusat, banyak lembaga non pemerintah juga menyelenggarakan kegiatan pendidikan. Banyak institusi pendidikan non negara yang bertahan dari masa ke masa, termasuk institusi pendidikan yang bercorak tradisional, khususnya lembaga pendidikan Islam seperti Nadwatul Ulama di Lucknow dan Deoband. Terkait kebijakan wajib belajar, hampir semua negara bagian mewajibkan semua anak berusia antara 6 sampai 14 tahun untuk bersekolah. Sistim ini menjamin pendidikan dasar selama delapan tahun, pendidikan menengah pertama selama dua tahun, dan pendidikan menengah tinggi selama dua tahun. Para siswa yang lulus dari sekolah menengah atas dapat melanjutkan ke salah satu dari seratus lebih perguruan tinggi dan ribuan kampus India. Terbesar adalah Universitas Delhi. Berikut tabel 2, persentase tingkat pendidikan berdasarkan agama:

Tabel 2: Tingkat Pendidikan berdasarkan agama

\begin{tabular}{|l|l|l|l|l|l|l|l|l|}
\hline No & Komunitas & $\begin{array}{l}\text { P e n d. } \\
\text { Dasar }\end{array}$ & Men. & $\begin{array}{l}\text { Men. } \\
\text { kedua }\end{array}$ & $\begin{array}{l}\text { M e n. } \\
\text { Atas }\end{array}$ & Dipl & Sarj & $\begin{array}{l}\text { Tanpa } \\
\text { ket. }\end{array}$ \\
\hline 1 & Semua agama & 55,57 & 16,09 & 14,13 & 6,74 & 0,72 & 6,72 & 0,02 \\
\hline 2 & Hindu & 54,91 & 16,18 & 14,25 & 6,92 & 0,71 & 7,01 & 0,01 \\
\hline 3 & Muslim & 65,31 & 15,14 & 10,96 & 4,53 & 0,41 & 3,6 & 0,05 \\
\hline 4 & Kristen & 45,79 & 17,13 & 17,48 & 8,7 & 2,19 & 8,71 & 0,01 \\
\hline 5 & Sikh & 46,70 & 16,93 & 20,94 & 7,57 & 0,90 & 6,94 & 0,02 \\
\hline 6 & Buddha & 54,69 & 17,52 & 14,09 & 7,65 & 0,35 & 5,7 & 0,01 \\
\hline 7 & Jain & 29,51 & 12,27 & 21,87 & 13,84 & 1,03 & 21,47 & 0,01 \\
\hline 8 & Lain-lain & 62,12 & 17,48 & 11,24 & 4,55 & 0,55 & 0,26 & 0,01 \\
\hline
\end{tabular}

Sumber: Sensus Penduduk India 2001

Data di atas memperlihatkan bahwa tingkat lulusan berdasarkan agama memiliki variasi di antara penganut agama-agama. Pemeluk Islam tampak masih lebih banyak berada di level lulusan pendidikan dasar, tertinggi dari rata-rata penganut agama lain. Di level sarjana, Muslim juga tertinggal dari pemeluk agama lain, dan hanya lebih tinggi dari "lain-lain". Di level sarjana plus diploma, para pemeluk Jainisme menunjukkan prosentase tertinggi $22,50 \%$, disusul pemeluk Kristen dengan 10,90\% .

Berikut tingkat melek huruf dan buta huruf di antara pemeluk agama di India, Tabel 3, sebagai berikut: 
Tabel 3: Rasio Melek Huruf Komunitas Minoritas Di India

\begin{tabular}{|c|l|c|c|c|c|}
\hline No & \multicolumn{1}{|c|}{$\begin{array}{c}\text { Komunitas } \\
\text { Minoritas }\end{array}$} & $\begin{array}{c}\text { Rasio melek } \\
\text { Huruf 2001 }\end{array}$ & $\begin{array}{c}\text { Perempuan } \\
\text { melek huruf }\end{array}$ & $\begin{array}{c}\text { Rasio melek } \\
\text { huruf 2011 }\end{array}$ & $\begin{array}{c}\text { Perempuan } \\
\text { melek huruf }\end{array}$ \\
\hline 1 & Semua India & 64,84 & 53,67 & & \\
\hline 2 & Muslim & 59,1 & 50,09 & $67,6 \%$ & $50,3 \%$ \\
\hline 3 & Kristen & 80,3 & 76,19 & & \\
\hline 4 & Sikh & 69,4 & 63,09 & & \\
\hline 5 & Buddha & 72,7 & 61,69 & & \\
\hline 6 & Jain & 94,1 & 90,58 & & \\
\hline 7 & Parsi/Zoroaster & 97,9 & 97 & & \\
\hline
\end{tabular}

Sumber: Indian Minorities in Higher Education, 2015, 48.

\section{Minoritas dan Sistem Kasta}

Selain minoritas agama, India juga mengenal tribes minority (minoritas suku) dan kasta. Kelompok rentan dari berbagai golongan minoritas ini dijamin hak-haknya oleh UndangU-undang, serta secara operasional dilaksanakan oleh National Commission for Scheduled Tribes untuk kelompok suku-suku yang rentan dan National Commission for Scheduled Caste untuk menjamin hak-hak kasta rentan yaitu Dalit dan The Other Backward Classes/Caste (Ahuja, 2008, 177-179). Selain komisi nasional, di India juga ada kementerian khusus, Ministry of Tribal Affairs (Wawancara dengan Paven Dafar, 3/11/2016).

Institusi khas India yang terkenal adalah sistem kasta, di mana faktor keturunan menentukan kelas sosial seseorang. Institusi ini dikembangkan dari kebiasaan bangsa Arya awal dalam membagi orang sesuai dengan pekerjaan yang mereka lakukan. Sistem asli meliputi empat kasta, yaitu Brahmana, kasta tertinggi, adalah pendeta; Ksatria adalah tentara dan pemimpin pemerintahan; Waisya adalah pedagang dan petani; dan Sudra adalah pengrajin dan buruh.

Kelompok kelima, Dalit (yang berarti tertindas), berkembang sebagai kelompok rentan setelah empat kasta arus besar. Mereka disebut untouchables atau tak tersentuh. Ini karena mereka berada di luar batas-batas kasta, atau orangbuangan. Penggunaan istilah untouchables ${ }^{1}$ dilarang pada saat kemerdekaan. Sejak tahun 1951, banyak orang Dalit memperoleh manfaat dari program afirmatif pemerintah. Pada tahun 1997, saat India merayakan 50 tahun kemerdekaannya, K.R. Narayanan menjadi presiden pertama yang terpilih dari kasta Dalit. Meski demikian, diskriminasi terhadap kaum Dalit tetap kuat, terutama di daerah pedesaan.

Sistem kasta saat ini lebih longgar daripada sebelumnya. Meskipun sistem ini masih sangat mempengaruhi struktur sosial negara. Anggota dari suatu kasta, biasanya hidup di lingkungan kasta yang sama. Strategi pemukiman yang melanggengkan klaster kelas sosial, tentu saja menyimpan potensi konflik secara laten. Rendahnya akses terhadap sosial ekonomi, pendidikan membuat orang India yang dilahirkan dalam sebuah

1 Jumlah kaum rentan dari suku-suku dan kasta rendah/Dalit sebesar 22,56\% dari seluruh populasi. Jumlah tersebut dapat dikategorisasi: 8,6\% kelompok suku asli (indigenous people) atau sekitar 104 juta, sedangkan Kasta rendah/Dalit sekitar 16,6\%, atau 201 juta menurut sensus 2011. Istilah untouchables akhirnya menjadi label, atau inferior status yang dianggap given. Dalam hal itulah pemerintah India menetapkan suatu program perlindungan, yaitu: penghapusan untouchabilty, perlindungan dari eksploitasi dan kekerasan sampai dengan pemberdayaan untuk meningkatkan kesejahteraan. Lihat: Ram Ahuja: Problem Social in India, ibid, hlm. 177; 186-199 
keluarga kasta rendah, tidak dapat melakukan mobilisasi sosial, karena kemampuan mengankses dan mengelola politik juga kurang baik, sehingga untuk mengubah diri ke kasta yang lebih tinggi. Padahal jalan keluar dari lingkaran kemiskinan adalah pendidikan dan kemampuan menumpuk kekayaan.

\section{Kebijakan terhadap Minoritas}

Dalam hal kehidupan keagamaan, India digambarkan berpotensi menjadi rumah semua agama, disebabkan aspek perlindungan terhadap kebebasan beragama serta perkembangan kelompok keagamaanyanghidupdengan relatifbaik. Di India juga terdapat banyak keunikan kehidupan keagamaan di masing masing negara bagian. Ada minoritas Kristen yang menjadi mayoritas di kotanya, $\mathrm{Goa}^{2}$ di bagian pantai barat India. Begitu juga bagaimana muslim di tempat yang lain. Hal baik yang perlu dikaji adalah cerita masa lalu antara Indonesia dengan India, baik dari aspek sejarah kedatangan agama-agama ke Nusantara, jalur sutra perdagangan, serta tentang knowledge route (jalur ilmu). Terdapat fakta bahwa lembaga pendidikan tinggi agama Buddha Nalanda di India, memiliki hubungan yang sangat erat dengan kerajaan Buddha Sriwijaya yang berpusat di Sumatera Selatan (wawancara dengan Iwan Pranoto, Atase Pendidikan dan Kebudayaan, Kedutaan Besar Republik Indonesia, New Delhi, India , 2/11/2016).

India menganut kebijakan afirmatif (affirmative policy) terhadap minoritas agama, mereka penganut agama Islam, penganut Kristen (Katolik dan Protestan),

2 Secara kultural mereka berbahasa Konkani, dan memeluk Katolik sejak pendaratan Portugis pada 1510. Lihat: John Correia Afonso S.J.: "To Cherish and to Share: The Goan Christian Heritage" Paper presented at the 1991 Conference on Goa at the University of Toronto, reprinted with permission from Narendra K. Wagle and George Coelho, (eds) South Asian Studies Papers, no 9. Toronto, Canada, dalam http://goacom.com/to-cherishand-to-share-the-goan-christian-heritage/. Diakses tanggal 16 November 2016. pemeluk Buddha, Sikh, Zoroaster dan Jainisme. Hal itu secara tegas diatur di dalam konstitusi serta di dalam Undangundang (UU) yang disebut National Commission for Minority, Act 1992. Menurut Naseem Ahmad, Chairman National Commission for Minority terdapat banyak penganut agama yang secara resmi belum diakui sebagai minoritas. Mereka adalah kelompok penganut Yahudi, Baha'i dan religious group yang secara kuantitas pemeluknya kecil, namun seringkali muncul dan menghilang. Kelompok yang biasa disebut sebagai new religious movement dikatakan seringkali muncul tetapi pemerintah membiarkan saja karena negara tidak mengatur kehidupan agama. Adapun tugas tugas yang diamanatkan kepada National Comission for Minority adalah memastikan bahwa seluruh kelompok minoritas yang secara resmi disebutkan dalam konstitusi terjamin hak-haknya, mulai dari hak politik, sampai dengan pengembangan budayanya. Praveen Davar, anggota National Commission for Minority (Wawancara 3/11/2016), menyampaikan bahwa masalah-masalah kasuistis yang berkaitan dengan agama di India tidak terlalu banyak dan cenderung menurun. Beberapa kasus terkait minoritas sudah ditangani secara lokal di tingkat negara bagian, seperti Uttar Pradesh. Minoritas sendiri didefinisikan sebagai populasi kecil yang diasosiasikan dengan pemelukan agama yang ada di India.

Selain Komisi Nasional untuk Minoritas, India juga memiliki Kementerian Urusan Minoritas (Ministry Of Minority Affairs). Kementerian ini lebih banyak bekerja untuk mendukung kegiatan pendidikan yang diselenggarakanuntukdanolehminoritas. Mereka menyiapkan dana selama lima tahun anggaran untuk meningkatkan sumber daya apa yang disebut dengan backward community (Muhammad Allam, 2008 hal 83-98). Perlindungan minoritas adalah isu penting bagi Komisi Nasional. 
Mereka berkewajiban hak-hak kelompok minoritas sebagai warga negara, terjamin dengan baik, bukan hanya dalam hal urusan kasus per kasus, namun juga dalam mengembangkan program dan kegiatan terencana di hampir semua negara bagian di India. Banyak kisah sukses yang diceritakan, di antaranya keberhasilan advokasi terhadap penyediaan lahan pemakaman untuk minoritas. Kasuskasus yang menyangkut pemakaman, dikatakan oleh Praveen Davar tidak terlalu banyak, setidaknya berdasarkan dokumen laporan tahunan komisi, menyangkut kebijakan pemakaman yang layak bagi mereka yang memerlukan penguburan jenasah, telah banyak tertangani. Dalam hal ini, perjuangan terhadap aturan pemakaman terjadi di Lucknow.

Komunitas muslim di Aligarh memiliki peran cukup penting sebagai minoritas yang memiliki nilai tawar cukup tinggi. Keberadaan Aligarh Muslim University (AMU) yang didirikan oleh Sir Seyd Ahmad Khan, berkontribusi terhadap kaum kecil dengan pendidikan yang murah, terutama bagi mereka yang disebut backward community dan the others caste (kasta-lain-lain) yaitu level antara kaum Dalit dengan Sudra. "Kasta lain-lain" inilah yang disematkan kepada muslim kelas menengah, dalam maknanya yang kultural. Peran Sir Syed Ahmad Khan dalam hal mendirikan Aligarh Muslim University (AMU) menampakkan hasil yang sangat signifikan teruatama untuk memberi layanan pendidikan terhadap minoritas tidak hanya kepada muslim saja, namun kepada mereka kelompok rentan di India. Meskipun nama resmi universitas tersebut bernuansa keislaman dan sistem pendidikan dibentuk bernafaskan Islam, mahasiswa yang beragama non-Islam cukup banyak. Perpustakaan Universitas ini yang diklaim terbesar di India, terlengkap koleksinya.
Ketua Jurusan Teologi Syi'ah AMU, Syed Ali Muhammad Navqi menjelaskan, studi di jurusan tersebut ditekankan kepada aspek hubungan internal umat Islam, serta bagaimana penganut mazhab Syiah sendiri hidup di India, khususnya Aligarh (Wawancara 4/11/2016). Menurut Ali Muhammad Navqi, hubungan SunniSyiah di India sangat kondusif, masingmasing pihak telah bisa sama-sama memahami perbedaan dan persamaan masing masing. Tidak banyak hal-hal yang menimbulkan ketegangan mazhab maupun teologis. AMU sendiri memiliki dua Jurusan Teologi, Syi'ah dan Sunni. Mereka yang lebih dekat pemahaman teologisnya kepada Syiah akan diarahkan dan terdaftar sebagai mahasiswa yang akan belajar tentang keagamaan Islam dalam versi Syiah. Begitu juga sebaliknya jika berlatarbelakang Ahlussunnah Wal Jamaah, maka akan diarahkan kepada Jurusan Teologi Sunni.

Tawqueer Alam Falahi (wawancara 4/11/2016) dari Jurusan Teologi Sunni (Department of Sunni Theology) AMU menyampaikan, bahwa konsepsi perlindungan minoritas yang telah diatur dalam konstitusi, merupakan dasar dan modal bagi muslim India untuk menjadi bagian dalam semua hal. Ditegaskannya, muslim di India adalah warga negara India sepenuhnya. Muslim tidak menempatkan diri sebagai pihak yang melawan atau berhadap-hadapan dengan kebijakan menyangkut hak-hak minoritas.

Di sisi lain, ada beberapa agama dan kelompok agama yang tidak diakui sebagai minoritas, terutama Baha'i. Eksistensi Baha'i secara sosial diakui di India. Kegiatan sosial dan perannya dalam hal penyediaan layanan sosial sangat diterima dan cukup memberi warna tersendiri bagi masyarakat India. Sepak terjangnya yang menembus warna dan kasta menjadikan Baha'i menjadi satu komunitas yang berkembang dengan 
pesat. $^{3}$ Program penyediaan layanan kesehatan dan pendidikan mereka cukup menarik simpati. Meskipun sebagian besar dari penganut Baha'i adalah mereka yang memiliki penghasilan cukup mapan, kehadiran kelompok rentan di kalangan Baha'i diterima dengan baik. Metode subsidi silang yang dilakukan oleh pemeluk Baha'i yang tidak memandang agama memberikan kesan tersendiri dari beberapa pihak yang berdiskusi tentang agama tersebut. ${ }^{4}$

Dalam hal istilah "minoritas" yang digunakan dalam penelitian ini jika merujuk kepada Muslim di India, ada kalangan Muslim India yang mempertanyakannya. Hinduisme sendiri bagi sebagian kalangan mereka dipahami sebagai kultur di India (wawancara dengan Profesor Saed Saheed dari Jamia University, 7/11/2016) $)^{5}$ sehingga keberadaaan Muslim sebagai minoritas agak disangsikan oleh Maulana Salman dari Darul Uloom Lucknow, dan Tanvir Haziq dari Indian Islamic Cultural Centre. Mereka meyakini bahwa Muslim bisa dikatakan mayoritas di tengah-tengah kultur Hindu yang mempunyai berbagai macam variasi kepercayaan, yang dianggap sebagai entitas tersendiri. Maulana Salman menjelaskan bahwa dalam Hindu itu berbagai agama ada di dalamnya, tidak hanya Jainisme tetapi berbagai kelompok keagamaan sebagai entitas agama yang berdiri sendiri. Adapun minoritas sendiri dapat

3 Wawancara dengan Zena Soreebji, unsur TBCI yang berpusat di New Delhi, didampingi satu pengurusnya. Ungkapan tentang perkembangan pesat dari Baha'i diungkapkan oleh Bilal Ahmad Kutty, professor kajian Islam AMU.

4 FGD dengan anggota PPI India: Jaenal Abidin, Nasir, Bayu, Brenny Ibrahim, Faiqoh, Samuel, Agus., tanggal 4 November 2016 di Aligarh.

5 Hindu sebagai kultural juga diungkapkan oleh banyak pihak, Maulana Salman dari Darul Uloom, Nadwatul Ulama, Lucknow menyatakan hal yang sama. Begitu juga dengan jajaran pimpinan Indian Islamic Cultural Centre dipahami sebagai tribal minority, religion minority dan caste minority. Ketiga model konsep tersebut berkembang, sampai pada keterpenuhan hak sejalan dengan masing masing konsep. Bagaimana hak sebagai minoritas suku terpenuhi, hak minoritas kasta terpenuhi, kemudian hak minoritas agama juga terpenuhi. Ini menjadi serangkaian isu politik, sehingga pasang surut perlakukan terhadap minoritas kerap kali terjadi.

Bagaimana

kenyataannya perlakuan negara terhadap minoritas? Mengutip tulisan mahasiswa doktoral di Aligarh Muslim University, Jaenal Abidin, mengamati kasus gugatan Perdana Menteri Modi terkait status institusi minoritas ${ }^{6}$ :

Pemerintahan Modi (pemimpin Partai BJP dari Koalisi NDA) pada 4 April 2014 menarik kembali upaya banding yang telah diajukan oleh pemerintahan koalisi UPA (dipimpin oleh Perdana Menteri Manmohan Singh dari Partai Kongres) kepada Mahkamah Agung, tentang penolakan terhadap putusan Pengadilan Tinggi Allahabad 2005, yang menyebutkan bahwa Aligarh Muslim University (AMU) bukan institusi minoritas (The India Today, April 4, 2016). Langkah intoleransi dan tidak simpatik terhadap kaum minoritas tersebut ditunjukkan koalisi NDA yang dipimpin oleh partai BJP. Sikap ini tidak hanya akan mengancam AMU, tetapi cenderung akan digunakan untuk mempolitisasi seluruh isu yang berkaitan dengan lembaga minoritas di India. Alasan pemerintah India tidak mengakui AMU sebagai sekolah khusus minoritas, karena institusi minoritas untuk agama tidak dapat dibenarkan di negara sekuler seperti India. Apabila status institusi minoritas dicabut, maka akan berdampak kepada struktur dan pola seleksi mahasiswa.

6 Jaenal Abidin: Sir Syed, AMU dan Perselisihan tentang Universitas Kelompok Minoritas, makalah disampaikan dalam FGD, 4 November 2016

Jurnal Multikultural \& Multireligius Vol. 17 No. 1 
Kuota 50\% kursi bagi komunitas Muslim akan dihapus, sehingga mereka harus bersaing secara terbuka dengan (komunitas) Scheduled Caste, Scheduled Tribes, dan Other Backward Classes (kasta rendah) dalam memperebutkan kursi mahasiswa AMU.

Di sisi lain, Fredik Kerketta, seorang Katolik di AMU, menjelaskan posisi umat Katolik sebagai minoritas di India. Eksistensi mereka diafirmasi dalam kontitusi, yang sepenuhnya menjamin hak-hak sipil mereka terutama berkaitan dengan hubungan horisontal. Namun, penganut Kristen sempat mengalami berbagai perlakuan kurang baik di dalam kehidupan sehari-hari. Kasus pengrusakan dan kekerasan yang mereka alami, terutama terjadi pada momenmomen politik, di banyak negara bagian. Nasib kurang baik dibandingkan pemeluk Islam dialami oleh mereka penganut Kristen, seperti halnya di negara Asia lain, istilah Kristen mengacu kepada Katolik dan Protestan. Persekusi aktif dan kerap kali terjadi di berbagai negara India.

\section{Relasi Antarumat Beragama}

Relasi antarpenganut agama di India sebenarnya tidak terlalu mengalami permasalahan yang signifikan, terutama jika menyangkut hubungan kehidupan keseharian. Memang dialog antar keyakinan tidak terlalu intens sampai di tingkat bawah, namun pemilik entitas agama sudah dapat saling memahami dan jarang menimbulkan kesalahpahaman yang berujung konflik.

Secara konseptual, pembangunan harmoni telah tumbuh di banyak kalangan, meskipun secara teknis upaya upaya membangun kerukunan lebih banyak dilakukan oleh LSM. Hubungan yang kurang harmonis antara pemeluk Hindu dan Muslim sebagian besar dipicu oleh politik, kebijakan dan gerakan partai BJP (Baharat Janaphia Party) yang memberikan tekanan kepada isu isu ultranasionalismenya. Dibalik gerakan BJP itu tampak adanya rantai hubungan dengan kebangkitan gerakan militan Hindu di India.

Tidak semua hubungan antarumat beragama berjalan mulus di India. Kasus masjid Babri di Ayodya, di negara bagian Uttar Pradesh, menimbulkan ketegangan yang berulang-ulang, karena perbedaan pemahaman sejarah dan keyakinan. Umat Hindu meyakini di tempat itu Krisna dilahirkan, ${ }^{7}$ sedangkan bagi Muslim, mesjid tersebut juga bersejarah karena didirikan oleh Babur, kaisar pertama Dinasti Mughal, pada abad 16 M. (1574 M). ${ }^{8}$ Banyaknya situs peninggalan dinasti Mughal (Islam) di masa lalu seperti Red Fort atau Taj Mahal di Agra, menunjukkan rangkaian sejarah tentang peran Islam di India yang masih terlihat sampai sekarang. Namun, hal itu sekaligus menunjukkan, sebuah rezim dinastik yang berkuasa ratusan tahun, tidak juga mengubah kultur kebudayaan Hindu menjadi bercorak Islam (Faiqoh pada FGD, 4/11/2016). Hal ini merupakan poin tersendiri untuk memahami berbagai aspek yang berkaitan dengan logika yang berseberangan dengan fakta kehidupan sosial keagamaan India saat ini. Supremasi kekuasaan dinasti yang menjulang tinggi, tidak cukup signifikan melakukan perubahan sosial keagamaan dan kultur India secara umum. Seperti disebutkan oleh beberapa narasumber yang telah diwawancarai, Hindu adalah kultur di India. Melalui pengamatan terhadap kehidupan keagamaan, identitas keagamaan dan kebudayaan, orang per orang bisa dipahami. Katakanlah, hanya dengan melihat pakaian yang digunakan,

7 Krisna sendiri dianggap sebagai manifestasi Tuhan, avatara Tuhan.

8 Penelusuruan Jaenal Abidin, disampaikan melalui FGD 4 Nopember 2016 di Aligarh. Juga: https:// www.eramuslim.com/berita/dunia-islam/tragedi-masjid-babri-ayodhy- india.htm\#.WEAolOZ97IU, diunduh 11/12/2016. 
meskipun sama sama menggunakan penutup kepala, dapat diketahui siapa penganut Sikh, dan siapa yang Muslim. Meskipun perempuan sama sama memakai kerudung, corak dan pernak pernik yang ada di kerudung itu secara kontras dapat membedakan corak agama pemakainya.

Ruang publik di India terbuka bagi seluruh kalangan, termasuk "homeless" yang menempati taman dan melakukan aktifitas keseharian di sana. Kawasan wisata memberikan perlakuan berbeda antara warga India dengan asing, terutama dalam hal tiket masuk ke situs keagamaan bersejarah seperti Taj Mahal dan Red Fort. Harga tiket bagi orang asing berkali-kali lipat mahalnya.

Prof. Saeed Saheed dari Jamia University menjelaskan bagaimana muslim mewujudkan harmoni di India (wawancara 9/11/2016). Saheed menempatkan pendidikan sebagai awal untuk membentuk karakter harmoni. Jika saja muslim belajar kepada Alquran maka karakter yang dimiliki akan paripurna, produktif, berpengetahuan, beradab dan berkontibusi bagia kehidupan manusia. Karakter manusia yang harmonis dengan alam dan lingkungan sosial itu tidak bisa dilepaskan dari pendidikan. Muslim terbentuk oleh setinggi apa mereka memahami pengetahuan yang diajarkan Al-Qur'an. Hinduisme menurut Saheed adalah kultural. Satu indikatornya adalah masyarakat India yang berlatar belakang Hindu cenderung vegetarian. Sebagain besar makanan yang ada di seluruh India lebih lekat dengan tumbuhan sebagai bahan utamanya, sehingga isu makanan halal bagi Muslim sendiri di tengah kultur Hindu India tidak menjadi masalah besar. Kalaupun ada beberapa makanan yang mengandung daging, maka telah terbentuk suatu kepercayaan dari penganut Islam, bahwa daging ayam dan kambing yang dikandung oleh makanan tersebut, dipasok oleh Muslim juga.

\section{Definisi Agama}

Konsepsi minoritas dan mayoritas penganut agama yang dilekatkan, tidak bisa dilepaskan dari definisi agama, konsespsi teologis Hindu yang cenderung terbuka, tentunya kontras dengan Abrahamik yang cenderung tertutup. Jika definisi agama mengunakan pendekatan Abrahamik, maka Hindu akan lebih dekat dengan kultural. Menurut Bilal Ahmad Kutty (wawancara 4/11/2016), professor kajian Islam di AMU, definisi agama tidak bisa dipisahkan dari kepercayaan terhadap Tuhan dan wahyu. Wahyu turun dan ditulis untuk membimbing manusia mencapai spiritualitas serta menjadi pedoman perilaku hidup dalam kebaikan, kebahagiaan di dunia sampai akhirat (Wawancara, 4 Nopember 2016). Dengan konsepsi wahyu seperti itu, diperlukan messenger sebagai kurir pesan Tuhan, sebagaimana dicontohkan secara gamblang oleh konsep kenabian Muhammad saw. sebagai penyampai risalah. Begitu juga nabi nabi sebelum Muhammad saw. mendapatkan wahyu. Jadi, agama tidak bisa dipisahkan dengan konsep kenabian, sebagai penyampai pesan kebenaran. Berikutnya tentang kitab suci, seorang messenger sebagai manusia memiliki batas waktu, dan karena itu keberadaan teks wahyu Tuhan untuk membimbing manusia tidak bisa juga diabaikan. Dengan demikian, bagi Bilal syarat suatu agama, harus memiliki tiga hal tersebut: konsepsi ke-Tuhanan, konsepsi wahyu dan kenabian, serta kitab suci.

Berbeda dengan pandangan di atas, Praveen Davar (wawancara 3/11/2016) mendefinisikan agama pada intinya sebagai seperangkat nilai, atau norma yang dapat memengaruhi manusia yang percaya untuk mengikuti pola dan aturan yang diperintahkan. Ketetapan norma yang mengatur itu termasuk didalamnya tata cara persembahan, kepercayaan terhadap kesucian baik itu 
Tuhan ataupun rohaniwan. Norma dan nilai itupun tidak dapat dilepaskan dari pengaruhnya sebagai kultur. Agama dan kultur sulit dibedakan.

Sedangkan penganut Baha'i Zena Soreebji (wawancara 9/11/2016) menyatakan bahwa definisi agama dapat dipahami dari berbagai perspektif, termasuk bagaimana penganut suatu agama memahami agama anutannya. Jadi, perspektif agama juga bisa dilihat dari pemeluknya. Soreebji sendiri menyatakan, jika agama didefinisikan dengan pengakuan adanya Tuhan dan wahyunya, kitab suci dan pembawa risalahnya, maka Baha'i telah memiliki syarat tersebut. Namun, kenapa di dalam konstitusi India keberadaan Baha'i tidak dimasukkan sebagai minoritas? Soreebji lalu menjawabnya sendiri, bahwa hal tersebut memerlukan perjuangan, sama dengan Sikh yang awalnya berjuang cukup lama untuk diakui sebagai entitas sendiri dan kini masuk dalam jajaran agama-agama di India.

\section{Potensi Konflik}

\section{Pendirian dan Perusakan Rumah Ibadah}

Ketegangan antar umat beragama di India seringkali dipicu oleh politik, yaitu berbagai kepentingan untuk menegakkan dominasi di level pusat/federal, dan pemenangan suara di negara negara bagian. Namun, perusakan rumah ibadah terjadi juga, sebagaimana dialami oleh gereja Kristen di Distrik Tadur, negara bagian Telangana. Perusakan dilakukan oleh kelompok Hindu Radikal. ${ }^{9}$

"Anti-Christian violence in India refers to religiously motivated violence against Christians in India, usually perpetrated by Hindu nationalists.

9 Disampaikan oleh Samuel, seorang mahasiswa asal Indonesia beragama Kristen, serta Fredik Kerketta penganut Katolik di Aligarh. Sebagai lampiran fakta dapat dikutip dari http://www.christianpost.com/news/onlychristian-church-in-indian-village-burned-down-by-hinduradicals-bibles-torched-133015/. Diunduh 01/12/2016.
The acts of violence include arson of churches, re-conversion of Christians to Hinduism by force and threats of physical violence, distribution of threatening literature, burning of Bibles, raping of nuns, murder of Christian priests and destruction of Christian schools, colleges, and cemeteries $^{\prime 10}$

"Kekerasan anti-Kristen di India merujuk kepada kekerasan dengan motif keagamaan terhadap Kristen di India, biasanya dilakukan oleh kaum nasionalis Hindu. Tindakan kekerasan termasuk pembakaran gereja, pengHindu-an kembali orang Kristen dengan paksaan dan ancaman kekerasan fisik, penyebaran bahan bacaan yang membuat ngeri, pembakaran Alkitab, perkosaan biarawati, pembunuhan pendeta Kristen, dan perusakan sekolah, lembaga pendidikan, dan pekuburan".

Selain persoalan Masjid Babri di Ayodya, tidak terlalu banyak catatan mengenai konflik rumah ibadah antara penganut Hindu dengan Muslim. Melalui pemisahan antara urusan agama dengan urusan pemerintahan dan negara, India cukup terbuka terhadap perkembangan agam-agama, bahkan kelompok agama baru dapat hidup berkembang sepanjang tidak melakukan gangguan terhadap pranata Hinduisme termasuk penghormatan terhadap alam dan lingkungan hidup, bahkan India dapat menjadi rumah untuk semua agamaagama yang mungkin muncul di abad ini atau nanti (Wawancara dengan Iwan Pranoto, 4 Nopember 2016).

10 Vinay Lal: "Anti-Christian Violence in India" tersedia dalam laman Vinay Lal Manas: India and Its Neighbors. UCLA College of Letters and Science. Organisasi Human Rights Watch juga mencatat, selama masa pemilihan umum legislatif September-Oktober 1999 dan perayaan kemenangan BJP (Bharatiya Janata Party, atau Partai Rakyat India) yang berafiliasi dengan ultranasionalis Hindu, telah terjadi pembunuhan pastor dan pemerkosaan terhadap biarawati di negara bagian Gujarat. Kejadian tersebut sebenarnya dimulai sejak 1998, yang mengalami peningkatan dari peristiwa sebelumnya berupa perusakan institusi gereja, sekolah dan biara. 


\section{Konversi dan Registrasi Agama}

Secara tegas dinyatakan dalam konstitusi India, bahwa negara menganut sekularisme, yang berimpilikasi kepada jaminan untuk tidak memandang rendah serta tidak mencampuri urusan pengakuan iman dari semua agama. Semua urusan agama akan dikembalikan kepada pemeluk dan lembanganya. Tetapi, meskipun negara tidak melakukan registrasi terhadap agama, jika ada satu kelompok menyebabkan terjadi disharmoni secara komunal di tengah masyarakat, maka pemerintah akan melarang keberadaan organisasi atau lembaga agama dimaksud. termasuk ke dalam disharmoni adalah tindakan terorisme. Semua gangguan disharmoni, terutama yang memiliki keterkaitan dengan pihak asing dianggap melanggar Foreign Contribution (Regulation) Act ("Religious Persecution In India", tersedia dalam eclj.org, diunduh 01/12/2016).

Kontroversi dari aspek kebijakan atau regulasi mengenai kehidupan keagamaan di India terjadi dengan munculnya Rancangan Undang-undang tentang Anti Konversi di dua negara bagian Orissa ${ }^{11}$ (2008) dan Gujarat (2002). Begitu juga dengan adanya larangan perayaan Asyura untuk mengenang wafatnya Imam Husain oleh pemerintah negara bagian Jammu dan Kashmir pada era 1990-an (http://www.greaterkashmir.com/ news/2014/Nov/5/curfew-like-restrictionsin-srinagar-on-ashura-30.asp, diunduh 1/12/2016). Harmonisasi antarperaturan cukup menjadi masalah dari aspek ilmu kebijakan. Aturan bisa saja ideal, namun tidak dapat dilaksanakan sesuai dengan konsepsi asalnya. Peraturan tentang anti konversi yang dilakukan di berbagai negara bagian dianggap sebagai upaya mencegah orang India memeluk agama

11 Negara bagian Orissa yang pertama kali menerbitkan Peraturan Anti Pemurtadan pada tahun 1967, lihat: http://www.thehindu.com/thehindu/ op/2002/12/17/stories/2002121700110200.htm. Diunduh 1 Desember 2016
Kristen atau Katolik. Setidaknya protes dilakukan oleh All Indian Christian Council yang menginginkan adanya kebebasan beragama. Di kemudian hari, BJP menjadikan RUU Anti Pemurtadan menjadi isu kampanye 2013, jika partainya menjadi pemenang pemilu pada tahun 2014 (Osuri, Goldie, "The Concern for Sovereignty in the Politics of Anticonversion" dalam Religion Compass., 2013, 385-393).

\section{Identitas}

Sistim kasta menjadi persoalan tersendiri di dalam sistem demokrasi. Kaum Dalit (Masyakat tidak berkasta) dan The Others Backward Caste -- kelompok yang lebih tinggi sedikit dari dalit. Seringkali dilekatkan kepada pemeluk Islam -- menjadi komoditas politik dan rentan terhadap pelecehan hak asasi manusia ${ }^{12}$. Pemerintah India tidak memberikan kolom agama dalam ID Card (baca: KTP), namun identifikasi orang per orang dapat dipahami melalui nama yang digunakan. Penganut Hindu, Muslim dan Kristen dapat dilihat dari nama yang digunakan dalam ID Card. Ketiadaan kolom agama dalam ID Card, menurut Praveen Davar (wawancara 3/11/2016) tidak menjadikan seseorang mengalami kesulitan dalam hal pelayanan sipil, bahkan sampai keperluan penguburan.

12 Dalam FGD. Jaenal Abidin mendeskripsikan persoalan kasta dan demokrasi bahwa setelah konflik bahasa sudah tidak populer, pokok masalah kembali ke Kasta. Dr. Ambetkaar dari Maharastra (India Barat), adalah pejuang kasta, pejuang kaum Dalit, yang dalam istilah Mahatma Gandhi adalah PARIA. Kritik Ambetkaar kepada Gandi adalah soal Kasta: Kalau Gandhi pejuang keadilan dan non violence, kenapa tidak mau memerjuangkan penghapusan kasta? Akhirnya Ambetkaar masuk Islam, dan ternyata di dalam Islam ada kasta juga. Untuk masuk Kristen Ambetkaar agak sulit karena dianggap agama penjajah, sehingga akhirnya menjadi Buddhis. Bagi banyak pihak, Ambetkaar inilah yang merancang konstitusitentang minoritas dan memiliki pengaruh dengan masuknya pasal per pasal. Ambetkaar juga yang mengisi $80 \%$ Konstitusi. Hanya dalam mengatasi persoalan Kasta, sulit dia mewujudkannya di konstitusi, meskipun menurutnya "Kasta ini bukan given, catur warna itu hanyalah fungsi sosial". Kaum Brahmin tetap ingin menjaga komunitasnya secara murni, dengan cara antara lain perkawinan endogamis, dan tradisi Sati. 
Tidak ada pembatasan akses kepada ruang-ruang publik.

Hal yang menjadi kontraproduktif menyangkut layanan sipil kembali pada persoalan kasta. Dalam formulir pekerjaan yang ditawarkan di seluruh India, tedapat kolom kasta yang nantinya berpengaruh terhadap nilai gaji yang diberikan oleh perusahaan. Mereka yang berkasta rendah meskipun, memiliki kemampuan bagus tetap mendapatkan gaji yang lebih rendah, dari mereka yang berkasta tinggi. Begitu juga dalam institusi pendidikan, terdapat pembatasan jumlah kasta rendah untuk pendidikan jurusan tertentu. ${ }^{13}$

\section{Institusi Minoritas Pendidikan Agama}

Maulana Saidurahman seorang Kepala Sekolah di Ma'had Darul Uloom, Nadwatul Ulama Lucknow, menyampaikan tentang adanya sikap fobia terhadap Islam di kalangan masyarakat di luar Islam (wawancara 10/11/2016). Menurutnya, ini adalah tugas yang tidak mudah untuk mengubah pandangan tersebut. Umat Islam di India rata rata miskin, mereka memiliki tingkat iliterasi yang sangat tinggi, terlalu hidup sederhana. Akses terhadap pendidikan dibatasi oleh biaya-meskipun biaya pendidikan di India sangatlah murahsehingga mereka akhirnya tidak menyekolahkan anaknya. Kalaupun sekolah, maka madrasah adalah pilihannya. Umumnya bekerja secara mandiri, karena mereka berpikir mencari uang hanya untuk kebutuhan makan dan kebutuhan primer saja. Mereka tidak mempunyai impian besar selain bertahan hidup saja. Hanya sebagian kecil dari mereka yang mengejar obsesi sampai mencapai posisi setingkat menteri, atau menjadi anggota parlemen.

13 FGD dengan PPI di Aligarh dan berbagi pengalaman PPI di New Delhi tentang adanya formulir di setiap urusan pekerjaan dan pendidikan.
Keberadaan Aligarh Muslim Univerity $^{14}$ sebagai lembaga dengan nama bernuansa Islam cukup menggambarkan bahwa meskipun India menganut sistem sekuler, negara tidak turut campur dalama urusan agama. Namun kehadiran universitas tersebut menjadi bahan statement, bahwa pendidikan agama mendapat tempat dan jaminan. Selain restriksi tentang anti pemurtadan di berbagai negara bagian, pendidikan agama sejatinya tidak diatur dan diurus secara resmi oleh pemerintah. Masing masing lembaga dapat menerapkan pendidikan agama sesuai dengan kebutuhan masyarakatnya. Di lembaga seperti AMU, kolom formulir disesuaikan dengan agama. Setidaknya ada tiga kolom, yaitu bagi calon mahasiswa Islam yang akan memilih kolom Sunni atau Syi'i, kolom khusus Hindu yang meminta informasi kasta. Bagi pemeluk selain Hindu dan Islam, tidak diminta mengisi denominasi agama atau struktur sosial (FGD dengan PPI India, 4 November 2016). Mereka yang beragama di luar Hindu dan Muslim dapat memilih mengikuti kelas agama atau materi ideologi umum (nasional). Dengan demikian, tindakan Perdana Menteri Modi yang akan berakibat membatalkan status lembaga minoritas bagi AMU, akan dapat memancing reaksi dan konflik antara Muslim dengan kelompok kasta rendah.

\section{Isu Syari'at Islam dan Inisiasi Penghapusan Talak Tiga}

Secara umum Maulana Salman, seorang Syaikh tokoh berpengaruh di Ma'had Darul Uloom Lucknow (wawancara 10/11/2016), menyampaikan bahwa di India, hubungan antar pemeluk agama terjalin dengan sedemikian

14 Didirikan pertama kali dengan nama Oriental Mohammaden College melalui negosiasi Syed Ahmad Khan dengan pihak Inggris, kemudian berubah menjadi Aligarh Muslim University sebagai institusi minoritas muslim 1924 (Sumber: https://www.amu.ac.in) serta hasil wawancara dengan pimpinan AMU 4 November 2016.

\begin{tabular}{l|l} 
HARMONI & Januari - Juni 2018
\end{tabular} 
baik. antarpemeluk dapat bekerjasama di ruang-ruang sosial, ekonomi serta pendidikan. Menyangkut potensi konflik, dikatakannya pasti ada, namun tidak terlalu berkemungkinan menjadi besar. Secara ringkas, isu penghapusan talak tiga mengemuka di berbagai seminar dan perbincangan anta intelektual muslim di India. ${ }^{15}$ Menurut Maulana Salman terdapat problem internal, karena secara konseptual sebagian ulama berpendapat bahwa seluruh talak itu adalah mutlak talak tiga. Inilah yang menjadi sorotan di ruang publik. Pemahaman talak tiga yang sering terjadi di India ialah dari jenis yang menyatakan bahwa semua talak adalah talak tiga. Konsepsi seperti itulah yang disalahpahami di internal muslim yang berakibat munculnya inisiasi pemerintah India untuk menghapusnya. Umat Islam tidak melakukan protes, tetapi menyelenggarakan banyak diskusi dan diseminasi informasi di berbagai ruang diskusi ilmiah yang menghadirkan pihak pemerintah.

\section{SIMPULAN}

Kebijakan penanganan minoritas di India memiliki bermacam tantangan, baik itu dari aspek harmonisasi antar peraturan maupun hambatan dalam sistem sosial. Kebijakan afirmasi terhadap minoritas yang secara jelas termaktub dalam pembukaan UUD Republik India adalah suatu langkah maju untuk menciptakan keadilan serta pemenuhan hak-hak sipil mereka yang secara jumlah kecil dibandingkan komunitas dominan, yaiyu Hindu Hindi. Sebagai negara yang dibangun berdasarkan keberagaman tentunya tidak mudah bagi Republik India mewujudkan pembangunan yang komprehensif, tidak saja menyangkut penyediaan kebutuhan dasar dan fasilitas

15 Informasi dari PPI India tentang berbagai event seminar di New Delhi yang membahas tentang talak tiga serta dinamika syari'a Islam di ruang publik di India. Isu talak tiga menghangat pada November 2016, saat pemerintah India ingin mengapusnya. publik yang memadai, namun juga harus memelihara keragaman, menjamin hak asasi semua warganegara, dan perbaikan kesejahteraan antargolongan yang seimbang. Tantangan yang hadir dari sistem sosial antara lain kebutuhan untuk seringkali berlaku harmoni, dengan nasionalisme sebagai suatu konsepsi yang menjaga integrasi. Bagaimana negara bisa membangun, jika kelompok rentan terus saja rapuh di tengah pembangunan? Uniknya, sistem demokrasi diterima begitu saja tanpa banyak gejolak, dan masyarakat patuh terhadap kepemimpinan yang berjalan. Tingkat kematangan demokrasi semakin terasa jika dikaitkan dengan kasus penarikan uang kertas 500 dan 1000 Rupee, pada 8 November 2016. Semua sektor usaha dan berbagai transaksi menghentikan lalu lintas pecahan uang tersebut. Meskipun ada rush pecahan kecil dari rupee di ATM dan Bank, tetapi tidak menimbulkan situasi yang chaos.

India adalah potret Indonesia dalam skala yang lebih dramatik. Kota-kota bergerak maju dengan fenomena homeless sebagai variasi gelap pembangunan. Beberapa hal sama dengan Indonesia, seperti bermacam suku, agama dan golongan yang bertahan di alam demokrasi dan mencari tempat secara evolutif, seiring dengan kemajuan pembangunan. Secara substansial, penelitian penanganan minoritas di India menyimpulkan sebagai berikut: 1), Perlakuan terhadap minoritas oleh negara India terhadap beberapa agama dilihat dari beberapa aspek, regulasi, implementasi program serta respon di masyarakat terhadap konsepsi perlindungan tersebut, dapat dianggap sebagai suatu inisiasi yang baik, meskipun ukuran keberhasilan belum dirumuskan secara ditampilkan dalam laporan tahunan. Penelitian ini belum mampu menghadirkan suatu gambaran regulasi keagamaan dan minoritas secara utuh dan komprehensif. 2), Dapat 
dipahami bahwa hubungan mayoritas dan minoritas di India terbangun dalam sebuah konsepsi yang dinamis. Dari aspek kesejarahan terdapat kerajaan Mughal, Muslim minoritas yang berkuasa dalam waktu yang lama, dan mewariskan suatu hubungan antarumat yang harus terus diperjuangkan. 3), Masih terdapat komunitas penganut agama, yaitu Baha'i dan beberapa kelompok keagamaan lainnya yang belum mendapat perlakuan setara, dan tentunya tidak memperoleh hak-hak perlakukan yang sama dari negara. Baik dalam bentuk non discrimination policy maupun affirmative policy.

\section{UCAPAN TERIMA KASIH}

Pada tulisan ini kami sampaikan terima kasih kepada Bapak Abd. Rahman Mas'ud sebagai Kepala Badan Litbang dan Diklat Kementerian Agama, dan kepada Bapak Muharam Marzuki,
Kapuslitbang Kehidupan Keagamaan. Selanjutnya, terima kasih kepada Duta Besar RI New Delhi beserta jajarannya, Konselor Kebudayaan KBRI New Delhi, Bapak Khairudin Siregar yang mendampingi selama penelitian di New Delhi beserta jajaran staf, tentu saja Prof Iwan Pranoto, Atase Pendidikan yang berbagi informasi berharga. Terima kasih kepada teman-temen PPI India, baik di New Delhi dan Aligarh, Farid seorang santri asal Malaysia di Lucknow. Secara khusus terima kasih kepada Mbak Faiqoh yang mendampingi sampai Aligarh, Brenny sebagai ketua PPI dan semuanya. Terima kasih kepada seluruh informan yang bersedia diwawancarai.

Tidak ketinggalan, terima kasih juga penulis tujukan kepada Mitra Bestari dan Pengelola Jurnal Harmoni yang telah memberikan catatan dan saran untuk perbaikan tulisan ini, hingga bisa diterbitkan pada Jurnal Harmoni edisi kali ini.

\section{DAFTAR ACUAN}

Allam, Muhammad, 2015. Indian Minoritas in Haigher Education, AMU Press, Aligarh, India

Ahuja, Ram, 2015. Social Problems In India, Rawat Publication, New Delhi. third edition, Ahuja, Ram, 2008. Indian Social System, Rawat Publication, California University.

Azra, Azyumardi, 2002. Reposisi Hubungan Agama dengan Negara, Kompas Media Utama, Jakarta

Beckford, James A., Demerath III N.J, 2007. The SAGE Handbook of Sociology of Religion Los Angeles, SAGE Publications

Busroh, Abu Daud, 2010. Ilmu Negara, PT Bumi Aksara, Jakarta.

Desai, A.R. 2012. Rural Sociology In India, Published by The Indian Society of Agricultural Economomics, Bombay.

Kashyap, C. Subhash, 2015. Our Contitution, An Introdauction to India's Constitution and Constitutional Law, National Book Trust, India, Nehru Bhawan, 5 Institutional Area, Phase-II Vasant Kunj, New Delhi.

Koentjaraningrat, dkk., 2003. Kamus Istilah Antropologi.Jakarta: Progres bekerjasama dengan Pusat Bahasa Departemen Pendidikan Nasional. 
Moleong, Lexy J., 2002. Metodologi Penelitian Kualitatif. Bandung: PT Remaja Rosdakarya.

Lal, Vinay,. "Anti-Christian Violence in India". Manas: India and Its Neighbors. UCLA College of Letters and Science

Osuri, Goldie, 2013. "The Concern for Sovereignty in the Politics of Anti-conversion". Religion Compass. Vol. 7, No.9

Reading, Hugo F., 1986. Kamus Ilmu-ilmu Sosial. Jakarta: CV Rajawali.

Schwartzberg, Joseph E (ed). 1993. A Historical Atlas of South Asia. Oxford University Press; Reprint, Subsequent edition

Tarique, Mohammad, 2008. Modern Indian History for Civil Services Examinations, McGraw Hill Education (India) Private Limited, New Delhi.

Varshney, Ashutosh, 2009. Konflik Etnis dan Peran Masyarakat Sipil Pengalaman India, (ptj. Siti Aisah dkk.). Jakarta: Balai Libang Agama, Departemen Agama.

Walsh, Judith E. 2006. A Brief History Of India New York, Fact On File

Internet:

Religious Persecution In India, eclj.org. 01/12/2016

http://www.thehindu.com/thehindu/op/2002/12/17/stories/2002121700110200.htm.

http://www.greaterkashmir.com/news/2014/Nov/5/curfew-like-restrictions-in-srinagaron-ashura-30.asp. Diunduh 01/12/2016.

http://www.who.int/phe/health_topics/outdoorair/databases/cities/en/.

http://www.christianpost.com/news/only-christian-church-in-indian-village-burneddown-by-hindu-radicals-bibles-torched-133015. 